\title{
Building to the Sky and the Height Paradox
}

\author{
Ali MM*
}

Professor Emeritus of Architecture, USA

\section{Opinion}

ISSN: 2639-0574

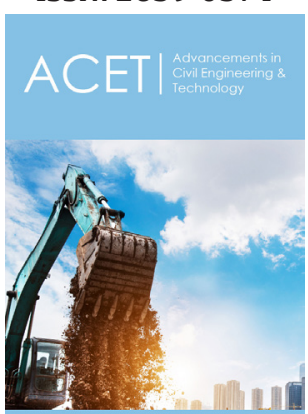

${ }^{* 1}$ Corresponding author: Ali MM, Professor Emeritus of Architecture, USA

Submission: 侮 May 21, 2019

Published: 侮 May 28, 2019

Volume 3 - Issue 2

How to cite this article: Ali MM. Building to the Sky and the Height Paradox. Adv Civil Eng Tech. 3(2). ACET.000560.2019. DOI: 10.31031/ACET.2019.03.000560

Copyright@ Ali MM, This article is distributed under the terms of the Creative Commons Attribution 4.0 International License, which permits unrestricted use and redistribution provided that the original author and source are credited.
In the wake of the catastrophic event of September 11, 2001 that brought down the World Trade Center buildings in New York, naysayers hastily predicted that it marked the end of future skyscraper construction. Engineers and architects who knew the history of tall buildings in cities, however, knew that these urban edifices did not surface fortuitously, but rather were essential to address the problems of increased human habitation as the world population continued to grow and people were moving from rural areas to cities. During the presentations of papers on tall buildings in different settings, I faced critics of tall buildings and tried to get across to them the logic behind the unrelenting development of tall buildings in the absence of alternate viable solutions to the problem of increasing high density in cities. Admittedly, tall buildings have a few shortcomings. Yet, there is no reason urban sprawl should be created or encouraged horizontally with its many associated drawbacks when the vast and empty sky is available to generate a vertical scale of cities. Many tall buildings including supertall (greater than $300 \mathrm{~m}$ ) and mega tall (greater than $600 \mathrm{~m}$ ) have been built in the first two decades of the 21st century. According to the Council on Tall Buildings and Urban Habitat (CTBUH) and the December 25, 2017/January 1, 2018 issue of Time magazine, 144 skyscrapers in cities measuring $200 \mathrm{~m}$ and over were built in 2017 , more than any other year in history. Tall building construction has been a global phenomenon for the last few decades and the race for height continues. But what maximum height can be attained by a skyscraper? Is sky the limit?

Tall buildings represent human aspirations for defying gravity and reaching to the heaven. A main reason why supertall and mega tall buildings can now be built in major cities of the world is that architectural practice has always relied on technological innovations such as in structures and materials. In general, technological advancements and breakthroughs in structural systems, foundations, elevators, lighting, fire protection, communication systems, smart materials--coupled with the latest digital revolution, have incrementally transformed the form, height, architectural design, and functions of skyscrapers. Structural system design to support skyscrapers of enormous scale is no longer a major impediment in building to great heights to the sky. A height of $828 \mathrm{~m}$ for Burj Khalifa of 2010 in Dubai has already been reached. It is currently the tallest building of the world. Interestingly, the needle-like form of the visionary Illinois Tower of 1956 by architect Frank Lloyd Wright is wittingly or unwittingly replicated in the Burj Khalifa building. The unbuilt 1-km tall Nakheel Tower project in Dubai, if built, would have exceeded the height of Burj Khalifa. The 1-km tall Jeddah Tower now under construction, when completed, is poised to be the tallest in the world.

Historically, the "Race for Height" began starting from the Park Row Building in New York which had already reached 30 stories in 1899. This height race culminated with the completion of the 102-story Empire State Building in New York in 1931. The height race continues as can be seen how far engineers have come since 1899. The height of a tall building, which defines the vertical scale of a city, often is dictated by the market-driven real-estate considerations; environmental and aviation factors; ego-driven prestige and a sense of competition. The development of the vertical scales of cities has gone through a few eras. The first period was in response to increasing urban density that yielded multistory buildings of an average of three to six stories limited by maximum walk-up distance in the 
absence of elevators. The advent of safe elevators in the mid-19 $9^{\text {th }}$ century in conjunction with the production of cast iron succeeded by steel initiated the second period with the first metal-framed skeletal construction with beam-column connections of the Home Insurance Building of 1885 in Chicago designed by William Le Baron Jenney. This type of structural framing allowed the design of taller buildings with curtain wall construction typically represented by 20 - to 30 -story high buildings with occasional exceptions that lasted until about 1950. Buildings taller than this height range with beam-column connection were not justifiable economically as the structural system became cost-intensive. Beginning with the 1950 s and especially the 1960s and onward, new height-based structural systems were developed, and the new height limit was defined by 40 to 60 stories, with some rising to 100 stories and above like the John Hancock Center and Willis Tower in Chicago, and the nowdestroyed World Trade Center in New York.

A common question is: what can possibly be the maximum height of tall buildings? This question is an oxymoron because there is no single or clear answer. There is a built-in paradox in this question whether we are looking for an optimum height or a feasible height limit. Optimum height depends on several practical considerations of which the market economy is the most vital. The optimum height is the economic height which is a time-dependent dynamic value that depends on the city's location: its construction infrastructure, material and labor cost, and the time of construction. As the building height increases, variable wind forces in different locations control the structural design and the energy demand also increases. Therefore, the unit cost, such as the cost per unit area of floor, increases. Another consideration is that the more expensive the land, the greater the optimum height of the skyscraper will be to recover the cost of investment and make it a profitable venture. Yet another consideration is vertical transportation using elevators. The taller the building, the more elevators are needed, and at some height, the ground floor will be occupied by elevators. This latter problem has been overcome to a large extent by transfer elevators, sky lobbies, and technological innovations. The maximum possible height is, however, a different matter. Technologically speaking, a mile-high building is possible today - although not without the associated challenges of required high strength materials, fire safety provisions, elevator systems, and constructability, amongst others.

For an exceptionally tall building, immense wealth is needed that it hard to procure and justify when most of the human race continue to live below poverty level. More importantly, we need to consider the human scale. The architectural expression of such buildings loses its meaning at great heights as our visual abilities diminish from the ground plane. By living and working at great heights, we lose contact with the ground-our natural habitat. While we can fly in airplanes and rockets at great altitudes, is it necessary or profitable to live and work at superhuman heights in monstrous towers that are anchored to the ground at human level? Who wants to live or work in a mile-high building susceptible to vibratory and oscillatory motion during high winds under the fear of being trapped in fire, failure of electricity, terrorist attacks, and other conditions related to health? Such buildings are truly vertical cities in the sky where people can live, work and play. Complete research results on density, safety, and socio-cultural perceptions for these vertical cities are still lacking and will perhaps remain so for many decades until many such towers are built, and lessons are learned from them.

There is thus no definitive answer to the questions, how tall are future skyscrapers expected to be and what could be or should be the maximum possible height? Undoubtedly, technological improvisation, innovative materials, energy efficiency, and re-creation of a natural ground plane-like environment and agricultural farming indoors, etc. will be some of the determinants of the height of future tall buildings. It is, however, likely that human ego and competitive spirit rather than practical considerations will ultimately determine the height of future mega tall buildings.

For possible submissions Click below: 